Working Paper 9519

\title{
DOES MEANS-TESTING WELFARE DISCOURAGE SAVING? EVIDENCE FROM THE NATIONAL LONGITUDINAL SURVEY OF WOMEN
}

by Elizabeth T. Powers

Elizabeth T. Powers is an economist at the Federal Reserve Bank of Cleveland. This article is based on work that originally appeared in her doctoral dissertation. The author thanks her dissertation committee, Alan Auerbach, David Neumark, and especially Stephen Zeldes, who provided many comments and suggestions. Jonathan Skinner, James Poterba, participants in seminars at the Wharton School of Business, the University of Pennsylvania, the University of Colorado at Boulder, the Federal Reserve Bank of Cleveland, Kansas State University, the University of Illinois at Urbana-Champaign, and the University of Kansas also made helpful suggestions and comments on the antecedents of this work. Kristin Roberts provided research assistance. This paper was presented at the 1995 NBER Summer Institute's Public Economics and Social Insurance workshop and at the 1994 Eastern Economics Association meetings.

Working papers of the Federal Reserve Bank of Cleveland are preliminary materials circulated to stimulate discussion and critical comment. The views stated herein are those of the authors and are not necessarily those of the Federal Reserve Bank of Cleveland or of the Board of Governors of the Federal Reserve System.

December 1995 


\begin{abstract}
This paper empirically tests whether the asset limit associated with the Aid to Families with Dependent Children (AFDC) program discourages wealth accumulation by actual and prospective participants. Prior to 1981, the AFDC asset test varied substantially across states, and this variation can be used to identify the effect of the limit on wealth. Wealth holdings for female-headed households (the primary recipient group for AFDC) for 1978 are estimated using data from the National Longitudinal Survey of Women. A $\$ 1$ difference in state limits results in an estimated $\$ .50$ difference in total net wealth holdings of female-headed households in different states. This qualitative finding of a significantly positive effect is reasonably robust with respect to a variety of specifications of the wealth equation and instrumenting of the limit to correct for the potential endogeneity of policy. After instrumenting, a $\$ 1$ difference in limits implies a difference in potential AFDC recipients' wealth holdings of $\$ .30$.
\end{abstract}


clevelandfed.org/research/workpaper/index.cfm 


\section{Introduction}

Aid to Families with Dependent Children (AFDC), Supplementary Security Income, Medicaid, and Food Stamps are the major U.S. welfare programs. Seldom-noted features of these programs are the penalties imposed when the welfare applicant's or recipient's asset holdings exceed specified, very low amounts. Past literature has overwhelmingly focused on the work disincentives created by welfare programs' earnings restrictions (see Moffitt [1992] for a survey). Recently, however, attention has begun to be paid to the notion that asset testing may have substantial, potentially damaging, effects on behavior. This paper presents empirical evidence on the impact of AFDC's asset-based means testing on the savings of female-headed households.

Hubbard, Skinner, and Zeldes (1995, 1994a, 1994b) explore means testing's potential impact on saving using a simulation model parameterized to the Michigan Panel Study of Income Dynamics (PSID). They demonstrate that for realistic levels of welfare income and age-eamings profiles, a lowlifetime-income family would be better off (in terms of expected lifetime utility) not to undertake significant savings, since asset holdings are heavily penalized by welfare programs, whose benefits are high relative to their autonomous income. When income is stochastic, the inclusion of asset-based means tests in an income maintenance program can also dramatically discourage saving by families who never actually experience income downturns serious enough to qualify for welfare, but who are at substantial risk of such downturns.

While Hubbard, Skinner, and Zeldes (1995) demonstrate that the pattern of asset holdings in the PSID is consistent with strong behavioral effects of asset tests, their simulations do not constitute a formal test of the hypothesis. If asset tests do inhibit saving in practice, this would have several interesting implications. First, it would support Hubbard, Skinner, and Zeldes's (1995) contention that the presence of asset-based, means-tested income maintenance programs explains the stylized fact that low-permanent-income families (as proxied by the household head's educational attainment) do not 
accumulate significant wealth over the life cycle. This, in turn, suggests that the life-cycle model might be appropriate for most households once the influence of asset-based, means-tested income maintenance programs was properly considered.'

The implication that asset tests inhibit saving would also heighten concerns that asset-based means testing may pose a threat to the long-term economic status of welfare-dependent individuals and their communities (for a full discussion, see Sherraden [1991]). There may be several transmission mechanisms for this effect. The asset test may affect the ability to finance education and training, contributing directly to long-term welfare dependency and even its intergenerational transmission. Another important goal of saving is home ownership. If failure to save reduces the incidence of home or business ownership, welfare-dependent communities may be weakened politically by a dearth of stakeholders. Without a buffer of wealth, individuals are apt to return more quickly to welfare during transitory income downturns. Finally, asset tests may deprive low-lifetime-income individuals of opportunities for learning to manage their finances and to set and achieve goals (that is, to adopt a longer planning horizon and to develop techniques appropriate to that horizon). These skills may be necessary for achieving a permanent exit from poverty. ${ }^{2}$ If asset tests inhibit saving in practice, relaxing limits on saving may increase the chances of a permanent exit from poverty for some families and encourage activities with positive externalities in poor communities. However, if there is no empirical evidence of a behavioral response to asset testing, raising limits may only increase caseloads.

This paper presents a simple test of the hypothesis that asset limits inhibit the wealth accumulation of a welfare-prone group--families with minor children that are headed by women. I use

\footnotetext{
${ }^{1}$ Hubbard, Skinner, and Zeldes (1995) suggest that alternative models, in which some groups behave fundamentally differently from others, are not compelling.

${ }^{2}$ In contrast, many government transfers directed at the middle class (e.g., the home-mortgage deduction and the tax-free accrual of pension wealth) foster exactly such "responsible" behavior. The case of Sandra, a young New Haven woman who spent her college savings because it threatened her family's AFDC eligibility, highlights this alleged double standard. As her Legal Aid lawyer put it, "Here you have a situation where other children would have been commended. They went to school full time. They worked part time. And they saved their money. The sad part of this is Sandra wasn't able to use this money for the purpose she had intended." Allegedly at the state's urging, the family spent their "excess" wealth on "clothes, jewelry, shoes, and perfume" (Hays [1992]).
} 
cross-state variation in the AFDC program's asset-testing policy to identify the effect of the asset limit in simple, empirical wealth equations. I restrict the analysis to the AFDC program and female-headed households for several reasons. Prior to 1981, the AFDC asset limit varied by state, while in most other major programs, such as Food Stamps, the rules have always been federally determined and uniform. Female-headed households are the primary users of AFDC, and the National Longitudinal Survey of Women, a data set that tracks a group of women who were between the ages of 14 and 24 in 1968 , collects asset data at five-year intervals.

The paper is organized as follows: The next section briefly describes the mechanism by which asset testing may discourage saving. It shows that in certain cases, wealth holdings may vary positively with the asset limit, if that limit constrains behavior. The final portion of the section maps out an empirical strategy. Section III describes the programmatic and household data used in the empirical work. Section IV discusses the empirical implementation and presents the findings, with an emphasis on testing the robustness of the positive relationship between the asset limit and wealth holdings. Finally, it examines the potential endogeneity of states' asset-testing policy with the cross-state asset distribution.

Section V summarizes and discusses the limitations and potential extensions of the analysis.

\section{Theory}

Several aspects of welfare policy potentially affect wealth holdings. First, the existence of the income floor provided by welfare smooths the lifetime income path, reducing the need for life-cycle (certainty-equivalent) saving, and for precautionary saving. By discouraging experience in the labor market and the development of human capital, the AFDC earnings test may also cause low permanent income and flat wage profiles. Under a life-cycle approach to saving, these factors alone can lead to low and flat patterns of wealth holdings. The fact that income from wealth is taxed at a 100 percent rate by the earnings test also discourages wealth accumulation. In both the theoretical discussion and the empirical 
work, I focus exclusively on the potential effect of the asset test (primarily characterized by the limit). The basic mechanism by which asset tests depress wealth holdings can be described using a simple, twoperiod model. The results of extending the model to the multiperiod case with eamings uncertainty, developed in Hubbard, Skinner, and Zeldes (1995), are described briefly.

A simple two-period model of consumption with certain income illustrates how means testing discourages saving. Assume that a family's first-period earnings $\left(\mathrm{Y}_{1}\right)$ exceed the AFDC income eligibility level $(\mathrm{G})$ and finance first-period consumption $\left(\mathrm{C}_{1}\right)$. For simplicity, assume that the gross rate of retum to savings is 1 and no assets are carried into the first period. Suppose there are no private earnings in period 2, so that second-period consumption $\left(\mathrm{C}_{2}\right)$ is financed from savings accumulated in period 1 $\left(A_{2}=Y_{1}-C_{1}\right)$, AFDC benefits $\left(B_{2}\right)$, or a combination of the two. Benefits can be written as

$$
B_{2}=\max \left\{0, G_{2}-A_{2}\right\}
$$

$\mathrm{G}_{2}$ is the "guarantee," or benefit payment to a zero-earning family of a given size in period 2 (for simplicity, assumed to be the same as eligibility income). $\mathrm{A}_{2}$ is assumed to be non-negative. Equation (1) indicates that benefits are reduced dollar for dollar with available private resources $\left(A_{2}\right)$. Figure 1 illustrates the budget constraint and possible consumption choices of the agent under this policy regime.

The critical feature of the agent's problem under asset-based means testing is the nonconvexity of the budget constraint. Hence, finding the solution to the agent's problem requires evaluating the lifetime utility of the local maximum if the agent chooses not to participate in welfare under any circumstances (consumption bundle A) against the utility of the local maximum given participation (here equivalent to receiving $\mathrm{G}$ in period 2 , or consumption bundle $\mathrm{B}$ ). Figure 1 illustrates the case in which it is globally optimal to consume all resources in period 1 and go on welfare in period 2 (i.e., utility at bundle B exceeds that at bundle $\mathrm{A}$ ).

Actual welfare policy imposes low but positive limits on the wealth holdings of applicants and participants. Let $\mathrm{D}_{2}$ denote a binary variable set equal to one if and only if wealth at the beginning of 
period $2\left(A_{2}\right)$ exceeds $L_{2}$, where $L_{2}$ is the limit imposed on the wealth holdings of welfare recipients. In this case, the benefit policy can be expressed as

$$
B_{2}=\max \left\{0, G_{2}-D_{2}\left(A_{2}-L_{2}\right)\right\}
$$

As long as wealth is less than the limit, there is no reduction in the benefit payment. Once wealth reaches the limit, "excess" wealth is taxed at a 100 percent rate until the point at which private resources exceed the guarantee. Beyond this wealth level, the agent is ineligible for the program. Obviously, even with a nonzero limit, today's saving choice has implications for next period's utility exceeding its usual role. Figure 2 illustrates the budget constraint and possible consumption choices of the agent under this policy regime, in the case in which it is marginally attractive to distort current consumption against the prospect of future welfare participation. Notice that if the guarantee were lower than that pictured, program participation would be suboptimal, and savings would jump up to their autonomous level. Nor would participation be optimal, ceteris paribus, if the asset limit were smaller; this demonstrates that higher asset limits weaken program targeting.

Blinder and Rosen (1985) investigate generic policies of the type illustrated in figure 1 , where $C_{1}$ and $\mathrm{C}_{2}$ are two arbitrary goods. They term these "notch" policies, after the shape of the budget constraint. Using simulations, they demonstrate that small guarantees are capable of inducing substantial consumption distortions. Thus, even if AFDC benefits are perceived as small by many female heads of families, this does not preclude the possibility of very large associated dissavings. In fact, although low, benefits are quite large relative to the typical income of a nonparticipating female-headed family.

Figure 3 illustrates the theory's implications for the relationship between limits and wealth holdings. Here, optimal wealth holdings (A) are plotted against the limit $(\mathrm{L})$. $\mathrm{A}^{\text {aut }}$ denotes the level of wealth holdings if the family relies entirely on its autonomous income. It is the level of wealth holdings that would occur in the absence of a welfare program. $A^{*}$ is the level of wealth that the family would hold if they had access to the welfare program, but it was not asset tested. Figure 3 is drawn assuming a fixed 
welfare program with a particular benefit level G, fixed autonomous income $Y$, and fixed preferences. The assumptions are such that for very low levels of $\mathrm{L}$, welfare participation is undesirable; hence, wealth $\mathrm{A}^{\text {aut }}$ is chosen. As the limit is increased, participation eventually becomes desirable, and positive constrained wealth accumulation occurs. Constrained wealth holdings grow one-for-one with the limit until the limit is large enough so that wealth holdings are unconstrained $\left(\mathrm{A}^{*}\right) .^{3}$

Hubbard, Skinner, and Zeldes (1994a, 1994b, 1995) extend this basic model of asset-tested welfare in two major ways. First, they extend it to include a realistic number of periods. The intuition of the simple two-period model turns out to be relevant for the multiperiod case. If welfare payments are sufficiently high relative to autonomous resources, the permanent-income poor find it optimal to participate frequently in the welfare program, despite the cost of the distorted consumption induced by the asset test. Hubbard, Skinner, and Zeldes (1995) also demonstrate that in the presence of uncertainty about future income or expenses, means testing can depress the wealth holdings of those who never actually experience income or consumption shocks leading to participation; this spreads the effects of means-testing to the rest of the (expected) low-permanent-income population. ${ }^{4}$ The empirical implication is that the behavioral effects of means testing may be readily discernible for potential future welfare participants, as well as for actual current and future participants. Although Hubbard, Skinner, and Zeldes do not explore the implications of nonzero asset limits specifically, it seems reasonable to expect the results illustrated in figure 3 to hold broadly in the more realistic multiperiod setting. Because of uncertainty about future incomes and expenses, these effects may also be evident for households not currently participating in the welfare program.

\footnotetext{
${ }^{3} \mathrm{~A}^{*}$ may lie above or below $\mathrm{A}^{\text {att }}$, depending on preferences.

${ }^{4}$ The "curse of dimensionality" when uncertainty is introduced in the nonconvex budget constraint problem is daunting, and computing the implied wealth distributions is a major technical achievement, even with current computing capabilities.
} 


\section{Empirical Strategy}

The basic empirical strategy is to estimate wealth equations for female-headed households, including the AFDC asset limit and related policies as explanatory variables. The fact that there is crossstate variation in the AFDC asset limit prior to 1981 makes it possible to identify the limit's effect on wealth. If female heads of families are sufficiently homogenous as a group, and if asset limits are sufficiently low overall, one would expect to find a positive relationship between limits and wealth holdings. That is, all else being equal, women residing in states with higher limits should typically hold more wealth.

However, there are several reasons why a positive relationship might fail to hold in the data. First, if limits are high relative to the desired life-cycle savings of the female heads, the limits will not bind, and one would expect no relationship between the limits and wealth. For example, because femaleheadedness is often not a lasting condition, the typical female head may quite rationally deplete the stock of wealth during this presumably low-income period, expecting it to be replenished upon marriage. Similarly, if the sample includes many high-permanent-income families, prospective welfare use is not an important consideration in determining wealth holdings.

Figure 3 illustrates a third reason for a nonpositive relationship between limits and wealth. Wide variation in asset limits, combined with the nonconvexity of the consumer's budget constraint when asset-tested welfare is an option, may induce a negative relationship between the limit and wealth. Consider the case of two women with identical characteristics who face the same welfare benefit schedule. Suppose however, that woman A's family lives in a state in which the limit is so low that welfare participation is never optimal, given her characteristics. Woman A holds wealth $\mathrm{A}^{\mathrm{aut}}$, as shown in figure 3. Woman B lives in a state with a higher limit and holds wealth low due to the desirability of participation under some circumstances. If very low limits are associated with "normal" levels of wealth, 
while higher limits induce consumption distortions, this will be manifested in a negative cross-sectional relationship between wealth holdings and limits.

\section{Program and Household Data}

\section{Characteristics of the AFDC Program}

The current AFDC program descends from the Aid to Dependent Children program, introduced in the 1935 Social Security Act. AFDC is the largest cash welfare program in the United States and has always clearly targeted female-headed households, defined here as a family unit with children under 18 and a mother or female guardian who does not cohabit with a husband or boyfriend. Federal AFDC legislation sets the criteria that each state's program must meet to qualify for its share of federal funding. These federal guidelines govern the rate at which benefits are reduced with labor earnings; determine the relationship between a standard of need (or minimum consumption requirement) and benefits; and set a maximum for participants' wealth holdings.

The asset test was made a requirement on states in 1955. The initial federal maximum was $\$ 1,500$ (all nominal dollars) per member of the recipient household. Five years later, the federal limit was increased to $\$ 2,000$ per recipient, with a family maximum of $\$ 8,000$. States tended to choose asset limits well below these maxima. Determination of the base to which the limits applied was also largely controlled by the states. Consequently, nominal limits varied widely, as did their application to gross versus net wealth; treatment of the owner-occupied home's value varied according to the interpretations of state courts (Lurie [1977]); many states imposed multiple asset tests across different categories of wealth (for example, savings accounts might have a lower limit than personal property). The asset limits also depended on family size in many states. This system lasted until 1981, when the federal government 
imposed strict guidelines for computing testable wealth, and the federal maximum was slashed to $\$ 1,000$ per family. ${ }^{5}$

To capture the effect of the asset test in the empirical implementation, four elements of policy are included as explanatory variables: the limit on nonhome property (including financial wealth and excluding vehicles); ${ }^{6}$ a binary variable indicating whether the limit is applied to gross or equity value; a binary variable indicating whether there is a housing test; and a binary variable indicating whether the primary vehicle is tested. Appendix A contains the values for these policy variables circa 1978 for the states in my sample. The policy variable of primary interest is the limit, which will vary positively with wealth if the hypothesis is supported (i.e., if wealth accumulation is constrained). To isolate the effect of the limit from that of family structure on wealth, in most specifications the limit for a family comprised of one adult and one child is used. The other policy variables are primarily considered as control variables, although their influences may also provide evidence of a significant effect of asset testing on wealth. The housing (/vehicle) test is expected to reduce wealth holdings by reducing housing (/vehicle) ownership, or the market or equity value of housing (/vehicles) held. However, in the case of certain components of wealth (e.g., liquid wealth) one might expect a positive effect of the housing/vehicle test via a portfolio effect. The valuation of property on a market or equity value implies a stricter asset test in all cases.

\section{Sample Construction and Characteristics}

The National Longitudinal Survey of Women (NLSW) is a panel survey of a group of women, beginning in 1968 when they were between the ages of 14 and 24 . Starting with that year, detailed data

\footnotetext{
${ }^{5}$ The other major change was in the benefit reduction rate, or implicit tax on labor, which rose from a statutory two-thirds tax on labor income to a 100 percent tax (after the fourth month of AFDC participation).

${ }^{6}$ Because multiple limits are possible on different forms of wealth within a state, the limit can be defined in various ways. I attempted to discern "the" limit associated with the broadest wealth definition, because states do not consistently place separate limits on detailed categories. I have experimented with a constructed limit on liquid wealth with mixed results.

${ }^{7}$ While this suggests interacting this variable with the limit, I did not find the coefficient for this interacted term to be significantly different from zero, and it is not included in the presentation below.
} 
on assets are collected at five-year intervals. The NLSW contains a variety of financial data and data on real property and debts. However, certain items are included in some states' asset tests for which no NLSW data exist. These include holdings of cash, pensions, durable goods, jewelry, and life and burial insurance. Data on whether a respondent received income from AFDC in the past survey year is also available for 1978 . In order to match the appropriate policy variables to an observation, the state of residence must be known, but this information is not released to users of the data base. Fortunately, states can be identified for about 60 percent of the 1978 sample by matching 1968-69 regional variables in the NLSW (e.g., educational expenditures by locality) to their published sources and deleting 1969-78 movers. ${ }^{8}$ This results in a sample of 402 female-headed families in 1978 , prior to deletions for missing values. Based on inspection of sample means, selection bias does not appear to be a problem.

Prima facie evidence from the sample suggests that asset limits should plausibly influence the wealth holdings of most female heads, if they influence those of any female heads, either because they are actual welfare recipients, legally bound by program rules, or because they are likely future recipients. There is striking homogeneity in incomes in the 1978 state-matched sample used in the empirical work below. Of all female heads, 90 percent have nominal income below \$13,475 (nominal dollars) in 1978 . The small income differences between those who are on welfare at some point in the sample year and those who are off welfare all year provide the most dramatic evidence. The ratio of mean participants' to nonparticipants' income is nearly 0.8 . Clearly, the pecuniary differences between autonomy and welfare are not large for most of these families, which suggests that the potential for future participation among the currently nonparticipating group is probably high. Therefore, it seems reasonable to treat all the families in the sample similarly in the estimation. ${ }^{9}$

\footnotetext{
${ }^{8}$ I am grateful to Jeff Gray for providing me with a list of state-respondent ID matches from his state-matching program.

${ }^{9}$ In a sample of two-parent families, for example, it would be necessary to develop criteria to distinguish those who are probably not concerned with welfare from those who are. While this is a potentially interesting issue for further research, it can reasonably be ignored in the case of female-headed households.
} 


\section{Empirical Implementation and Tests}

This section presents the findings from the estimation of various wealth equations, with an emphasis on exploring the robustness of the basic finding that the limit and wealth are positively related, as shown in the first subsection.

\section{Parsimonious Specification}

The literature contains a wide variety of empirical specifications of wealth. Wealth is often explained as a nonlinear function of contemporaneous income and personal characteristics (for an example in a context very similar to this one, see Feldstein [1995]). Because wealth is a state variable in the consumer's optimization problem, it presumably reflects all static characteristics, as well as the entire history of relevant variables for the consumer's optimization problem, including past policy. Therefore, lagged wealth should capture the cumulative effects of these factors, as well as past welfare participation. Because the sample is small, I begin with a "parsimonious" specification of the wealth equation which, in theory, contains the most information using the fewest variables. The parsimonious specification includes income terms, policy variables, and lagged wealth. ${ }^{10}$

Initially, I consider three definitions of wealth, constructed from the various components of household assets available in the NLSW. Gross and total net wealth include the total value of (respectively equity in) financial wealth, vehicles, housing, and other real property. Financial or "liquid" wealth includes savings accounts, stocks, and bonds. The asset limit and other measures of asset testing policy are constructed by state from published sources (the U.S. Department of Health and Human Services, selected years). In states where multiple limits govern different categories of wealth, a limit was constructed for combined real (nonhome, noncar) and financial property.

Table 1 presents the findings for the parsimonious level and log-linear models (sample means and standard deviations of all variables are presented in Appendix B). The parsimonious wealth equations

\footnotetext{
${ }^{10}$ Age terms were all insignificant, due to the age restriction of the NLSW sample.
} 
are estimated for all three definitions of wealth. All standard errors of the coefficient estimates are adjusted using White's (1978) heteroskedasticity correction. The models are estimated in both level and log versions. Simple tests (Davidson and Mackinnon [1981]) reveal that both the log and level specifications conveyed information distinct from the other; neither functional form emerged as clearly superior.

For the model in levels, the level of contemporaneous income appears to exert a significantly positive influence on all three types of wealth. The squared income term is not significantly different from zero at standard confidence levels (all significance levels refer to two-sided t-tests unless otherwise noted). For the net wealth equation in levels, wealth varies positively with the limit, as expected. A $\$ 1$ difference in the limit results in an estimated $\$ .48$ difference in wealth holdings. The housing test also appears to reduce total net-wealth holdings significantly. The other two policy variables, market valuation and the vehicle restriction, have no significant effect on any of the wealth measures in the model in levels, and the vehicle restriction has an unexpected sign in the case of net wealth. In the case of gross wealth, only the housing-test policy variable has a significant effect (negative, as expected). Of the policy variables, only the two-person limit has a modest effect on liquid wealth holdings (it is significantly positive in a one-sided test at the 90 percent level). In all three level specifications, the lagged endogenous variable is highly significant and positive, as expected.

The last three columns of table 1 present the findings for the log-log form. The elasticity of wealth with respect to income is first negative, then turns positive at higher income levels. The limit has a significantly positive effect in the cases of both net and gross wealth, and a marginally significant positive effect in the case of liquid wealth. The elasticities of total net and gross wealth with respect to the limit are both around 0.7 . The elasticity of liquid wealth with respect to the limit is 0.14 and is significantly greater than zero (in a one-sided test) at the 95 percent level. In the model in logs, the coefficient of the housing-test variable is never significantly different from zero. The gross versus equity valuation variable has a marginally significant positive effect in the cases of net and gross wealth, 
contrary to expectations. As in the level specification, past wealth is an important determinant of current wealth. For the remainder of the empirical work, I focus on the total net measure of wealth. Extended Specifications

Alternative empirical wealth equations in the literature suggest two important ways to modify the parsimonious specification. First, since saving can be defined $S_{t}=A_{t}-A_{t-1}$, wealth can be written $A_{t}=S_{t}+A_{t-1}$. This suggests the addition of variables expected to influence additions to wealth (' $S_{t}$ ') between 1973 and 1978. These might include changes in family size and the interim pattem of income, as in Skinner (1993). Unfortunately, it is not feasible to compute a consistent family income series for the period 1973-78 from the NLSW. Instead, factors are included which are thought to significantly influence income over the period, along with indicators of changes in family status; binary variables indicating a significant change in educational attainment (either high school or college graduation), and a positive or negative change in the number of the female head's dependents. Increased educational attainment has an ambiguous effect on final wealth via saving. While it may increase permanent income, and thus increase consumption and reduce saving, it may also indicate a positive jump in contemporaneous income, which would tend to increase saving. Increases or decreases in the number of dependents also indicate a significant change in family structure. Increases in the number of dependents raise family consumption requirements and may slow wealth accumulation, while decreases are expected to have the opposite effect.

In addition to (or in place of) lagged wealth, variables that represent static characteristics thought to have an important influence on 1978 wealth holdings are also included. These are binary variables indicating whether the female head was ever married, whether she is a high-school graduate, and the number of her dependents. Female heads who have been married are likely to hold more wealth, since they had access to their husbands' earnings and assets at some time in the past. Holding a high-school degree should also be associated with higher levels of wealth, since the individual is presumably in a higher permanent income group. 
Table 2 reports the findings for these extended models, again in both level and log-log forms. In the case with levels (column 1), lagged wealth seems to be an "absorbing" variable. That is, the static personal characteristics are redundant and add no explanatory power to the model. Nor are the “updating" variables reflecting important changes between 1973 and 1978 significant at standard confidence levels. The additional variables also have virtually no effect on the estimates of the influence of policy, which can readily be seen by comparing the first columns of tables 1 and 2 . Column 3 of Table 2 reports the analogous findings for the log-linear case. In contrast, even when lagged (log) wealth is included, the high-school-graduate variable has a significant positive influence on wealth. Having never been married marginally lowers wealth, as does an increase in the number of dependents between 1973 and 1978, as anticipated. However, as in the case of levels, the policy effects are robust with respect to the addition of these variables.

\section{Robustness with Respect to Lagged Wealth}

Table 2 also contrasts the estimates of the extended specifications with and without lagged wealth. While theory suggests that lagged wealth is an important state variable whose omission results in biased estimates, use of lagged endogenous variables should be treated cautiously. For example, autocorrelation in the errors may cause lagged wealth to be spuriously significant in the model, although additional evidence does not support this. ${ }^{11}$ However, autocorrelation may still be a problem when the true model includes lagged wealth, resulting in inefficient estimates. Unfortunately, data limitations prevent using a Hatananka estimator. ${ }^{12}$ All that can be done is to investigate the sensitivity of the findings with respect to lagged wealth.

The second column of table 2 presents the findings for the extended specification in levels when lagged wealth is excluded from the model. The current level of income, never having been married, and

\footnotetext{
"The coefficients of autocorrelation when lagged wealth is excluded from the specifications (not reported) are significantly smaller than the coefficients on lagged wealth in table 2.

${ }^{12}$ The problem is that the required additional lag of wealth would take the sample back to 1968, when many respondents are children living with their parent(s); alternatively, if the time-frame is shifted forward, the wealth observations from 1983, 1978, and 1973 straddle a significant change in policy regime occurring in 1981.
} 
being a high-school graduate are now the important determinants of wealth, although they explain little of its total variation. The interesting result of dropping lagged wealth is that the effect of the policy variables is no longer significant. While the estimated coefficient of the two-person limit is fairly robust to excluding lagged wealth, its estimated standard error increases. In contrast, for the log specification, the estimate of the effect of the limit is virtually unchanged by the inclusion or exclusion of lagged wealth, and it remains significantly different from zero.

\section{State Effects}

An important question is whether the welfare policy variables inadvertently proxy for statevarying characteristics that influence wealth holdings independently. For example, state-varying divorce laws may influence settlements. A state with policies generally favorable to women may encourage generous settlements and also set relatively generous asset limits for AFDC. The policy variables may also inadvertently reflect interstate variation in conditions like general economic opportunity, property values, and wages. For example, after controlling for interstate variation in welfare policy, Blank (1985) finds that female heads still face substantially different state economic conditions.

A straightforward correction is to augment the model with state-specific binary variables to adjust for all state-varying characteristics. Policy variables for the treatment of property, housing, and vehicles must be dropped, since they only vary by state. Variation in the number of children across households should provide sufficient state-independent variation to identify the effect of the limit from the state dummies. Table 3 presents the findings before and after the inclusion of state dummies. In the absence of the other policy variables, the effect of the limit is estimated to be somewhat weaker to begin with. However, it is still significantly different from zero at at least the 90 percent level in both $\log$ and level specifications and is significantly greater than zero at the 95 percent level or greater in a one-sided t-test. In both log and level versions, including state effects increases the magnitude of the estimated coefficient on the limit, although in the log version the coefficient is no longer significantly different from zero. 
clevelandfed.org/research/workpaper/index.cfm

\section{Endogenous Policy}

An important remaining concern is that the wealth distribution and asset-testing policies are determined endogenously. To take a simplistic example, consider two states in which the income distributions are identical, but suppose one state's wealth distribution is shifted farther to the right. In order to generate the same number of eligible recipients in each state, the state with higher mean wealth can set its limit higher. In this case, endogeneity biases towards a positive relationship between the limit and wealth.

One weak test whose failure would be a strong sign that the limit "reverse causes" the findings is to estimate the relationship between 1978 asset limits and 1983 wealth holdings. After the federal policy change in 1981 , all but a handful of states imposed an asset limit of $\$ 1,000$. Suppose that the positive relationship between 1978 wealth holdings and limits is simply due to states setting policy in response to their wealth distributions. If there is no behavioral effect of the limit on wealth holdings, there should be no response to the change in policy in 1981 , and 1978 asset limits should continue to be a good indicator of state-varying wealth characteristics. The lack of a significantly positive relationship between 1983 wealth and 1978 limits could result from either of two factors or from their combination. First, wealth may actually respond to policy, and asset-testing policy changed dramatically in 1981. Second, differences in relative state wealth distributions may have changed over the period for other reasons (including changes in welfare policy that have nothing to do with the asset test). This last possibility explains why the test is a weak one.

The parsimonious specification for levels in table 1 was re-estimated, substituting 1983 wealth as the dependent variable (findings not reported). Both specifications using 1978 wealth (the new lagged endogenous variable) and 1973 wealth (the original right-hand-side variable) as explanatory variables were estimated. In all cases, the coefficients of the policy variables were not significantly different from 
zero at all reasonable confidence levels, indicating a lack of strong evidence of reverse causality in the data.

An attempt is also made to correct for the possible endogeneity of policy by using a lag of the limit as an instrument. The earliest year prior to 1978 for which there are published data on the limit is 1974. About one-half of the states have some noticeable change in their asset-testing policy between 1974 and 1978. Although ideally one would instrument the binary policy variables as well, the published information for 1974 is less complete. The findings are presented in table 4. Without the other policy variables, the two-person limit is significantly positive in a one-tailed test at the 95 percent level or better

in both levels and log specifications without instrumenting. The findings are quite robust with respect to instrumenting, but the two functional forms yield contradictory interpretations of policy's role. The corrected coefficient for the limit is smaller in the levels version, but is still significantly greater than zero at the 90 percent level in a one-sided test. In the log specification, the limit remains highly significantly positive and its magnitude increases somewhat, suggesting that the uninstrumented coefficient is biased downward.

\section{Other Robustness Issues}

It is possible that the effect of welfare rules on current welfare participants generates the above findings, and that nonparticipants do not incorporate welfare into their contingent consumption plans. While this still supports the hypothesis that limits have an important effect on savings, the more interesting aspect of the hypothesis raised by Hubbard Skinner, and Zeldes--that, because of uncertainty, the effect of asset tests is to dampen wealth holdings for whole lifetime-income groups, regardless of actual participation--should be examined in more detail. Therefore, households that reported receiving AFDC income within the survey year were dropped, and the models were re-estimated for the remainder of the sample. The disadvantage is that only 256 observations remain in the sample. (Sample means and standard deviations for all variables are presented in Appendix B.) 
Table 5 presents the findings for the groups of nonparticipants in level and log versions of all four specifications: the parsimonious specification of table 1; the extended specification of table 2 ; the model with state effects of table 3 ; and the instrumented version of table 4 . The qualitative findings are strikingly similar to those for the entire sample, with one exception: When state effects are included, the family-varying limit is no longer significantly positive in the log-log specification. In nearly every case, the estimated magnitude of the limit's effect is larger in level models and smaller in log-log models when participants are excluded. There is no obvious explanation for this pattern.

Finally, all of the specifications were investigated for sensitivity to the exclusion of outliers. This was done by excluding observations associated with absolute standardized residuals exceeding two. This procedure tended to result in a handful of deletions (typically fewer than 10 in the full sample), and none of the specifications was substantively changed when re-estimated with the reduced sample.

\section{Conclusion}

This paper empirically tested the hypothesis that the asset-based means test affects the saving behavior of actual and prospective AFDC recipients. The approach has been to use state variation in asset limits prior to 1981 in order to identify the effect of the limit. In a parsimonious specification of the empirical wealth equation, a $\$ 1$ difference in two states' asset limits was estimated to result in a $\$ .48$ gap in the total net wealth holdings of female-headed households residing in the respective states. Altematively, a log-log specification resulted in an estimate of the elasticity of total net wealth holdings with respect to the limit of 0.7 . The robustness of these findings was explored along several dimensions. They were robust with respect to including additional explanatory variables. While the positive significance of the limit in the levels version of the model was not robust with respect to replacing lagged wealth with other characteristics, the estimated effects of policy in the log specification were quite robust to replacing lagged wealth. The estimated effect of the limit was also reasonably robust to the inclusion 
of state effects for both functional forms. The possibility that the limits are endogenous with the asset distribution led to the use of a lagged policy variable as an instrument for the two-person-family limit. The findings were reasonably robust with respect to instrumenting the limit in both level and log specifications. Finally, to estimate the impact of the limit via potential participation, the models were reestimated using the subsample of female-headed households not participating in AFDC in the year of the survey. The findings were quite robust with respect to this change in the sample.

Althought the findings provide support for the hypothesis, there are several potential areas for further research that may produce still more decisive findings. Perhaps most importantly, this work relies on the homogeneity of the female-headed household sample incomes to support the simplifying assumption that all female heads are potential program recipients with high enough probability so that the asset limit affects their saving behavior. ${ }^{13}$ The inability to discem gradations of the desirability of welfare may bias against finding a strong relationship between the asset test and wealth, if many members of the sample have little concern about future welfare use. ${ }^{14}$ This would be of particular concern when analyzing the effects of other welfare programs.

The treatment of the limit's potential endogeneity with wealth might also be refined. While instrumenting using lags is a promising approach, to do this with greater precision it is desirable to develop a model of the policy process. The various rules on housing, vehicles, and gross versus equity valuation are probably best modeled as being determined jointly with the limit in the policy process. Even had these other policy features not been beyond the scope of this paper, they would necessarily have been excluded because of data limitations.

Finally, as I mentioned early on, several other ways that welfare policy potentially affects wealth holdings might be incorporated into the analysis. The existence of the income floor provided by AFDC

\footnotetext{
${ }^{13}$ A necessary implicit assumption is that the desirability of welfare is similar across states, which is not supported by much of the empirical welfare literature, although the bulk of the variation may occur above a threshold sufficient to influence saving behavior.

${ }^{14}$ For example, Feldstein (1995) stratifies his sample of families potentially affected by college-scholarship rules by income.
} 
reduces the need for saving in anticipation of income declines. By discouraging experience in the labor market, the AFDC earnings test may result in low permanent income, implying lower wealth holdings at every age. Inexperienced workers may also face flat income profiles (that is, a combination of low earnings and AFDC), which flattens the age-wealth profile. The fact that the program taxes income from wealth at a 100 percent rate also discourages wealth accumulation. The integration of these myriad factors into a comprehensive analysis of welfare's influence on wealth awaits a richer treatment of the dynamics of welfare participation than has appeared in the literature to date. 
Appendix A: Policy Variables for Selected States, 1978

\begin{tabular}{|c|c|c|c|c|}
\hline State & Limit, 2-Person Family & Housing Test & Vehicle Test & Market Valuation \\
\hline Alabama & $\$ 1,750$ & no & yes & yes \\
\hline Arkansas & 2,250 & $\mathrm{y}$ & $\mathrm{y}$ & $y$ \\
\hline California & 6,600 & $y$ & $\mathrm{n}$ & $\mathrm{n}$ \\
\hline Connecticut & 250 & $\mathrm{y}$ & $\mathrm{n}$ & $\mathrm{y}$ \\
\hline District of Columbia & 2,000 & $\mathrm{n}$ & $\mathrm{y}$ & $\mathrm{y}$ \\
\hline Florida & 1,200 & $\mathrm{n}$ & $\mathrm{n}$ & $\mathrm{y}$ \\
\hline Georgia & 800 & $\mathrm{n}$ & $\mathrm{n}$ & $\mathrm{y}$ \\
\hline Hawaii & 575 & $\mathrm{y}$ & $\mathrm{y}$ & $\mathrm{n}$ \\
\hline Idaho & 2,000 & $\mathrm{n}$ & $\mathrm{n}$ & $\mathrm{n}$ \\
\hline Illinois & 200 & $\mathrm{n}$ & $\mathrm{n}$ & $\mathrm{y}$ \\
\hline Indiana & 700 & $\mathrm{n}$ & $\mathrm{y}$ & $\mathrm{y}$ \\
\hline Kansas & 1,000 & $\mathrm{y}$ & $\mathrm{n}$ & $\mathrm{n}$ \\
\hline Kentucky & 2,000 & $\mathrm{n}$ & $\mathrm{y}$ & $\mathrm{n}$ \\
\hline Louisiana & 1,000 & $\mathrm{n}$ & $\mathrm{y}$ & $\mathrm{y}$ \\
\hline Massachusetts & 1,000 & $\mathrm{n}$ & $\mathrm{n}$ & $\mathrm{y}$ \\
\hline Maine & 1,000 & $\mathrm{n}$ & $\mathrm{n}$ & $\mathrm{n}$ \\
\hline Maryland & 300 & $\mathrm{n}$ & $\mathrm{n}$ & $y$ \\
\hline Michigan & 2,000 & $y$ & $\bar{y}$ & $\mathrm{y}$ \\
\hline Minnesota & 15,500 & $y$ & $\mathrm{y}$ & $\mathrm{n}$ \\
\hline Mississippi & 1,500 & $\mathrm{y}$ & $\mathrm{y}$ & $\mathrm{y}$ \\
\hline Missouri & 1,500 & $\mathrm{n}$ & $\mathrm{n}$ & $\mathrm{y}$ \\
\hline Nebraska & 2,250 & $\mathrm{n}$ & $y$ & $\mathrm{y}$ \\
\hline New Hampshire & 1,000 & $y$ & $\mathrm{n}$ & $y$ \\
\hline New Jersey & 705 & $\mathrm{n}$ & $\mathrm{y}$ & $\mathrm{y}$ \\
\hline New Mexico & 1,950 & $\mathrm{n}$ & $\mathrm{n}$ & $\mathrm{y}$ \\
\hline New York & 3,000 & $\mathrm{n}$ & $\mathrm{n}$ & $\mathrm{n}$ \\
\hline North Carolina & 1,100 & $\mathbf{n}$ & $\mathrm{y}$ & $\mathrm{y}$ \\
\hline Ohio & 2,250 & $\mathrm{n}$ & $\mathrm{y}$ & $\mathrm{y}$ \\
\hline Oklahoma & 550 & $\mathrm{y}$ & $y$ & $\mathrm{y}$ \\
\hline Oregon & 2,250 & $\mathrm{n}$ & $\mathrm{n}$ & $\mathrm{y}$ \\
\hline Pennsylvania & 3,450 & n & $\mathrm{n}$ & $y$ \\
\hline South Carolina & 1,000 & $\mathrm{n}$ & $\mathrm{n}$ & $y$ \\
\hline Tennessee & 500 & $\mathrm{y}$ & $\mathrm{n}$ & $\mathrm{n}$ \\
\hline Texas & 3,000 & $\mathrm{n}$ & $\mathrm{n}$ & $y$ \\
\hline Utah & 2,250 & $\mathrm{n}$ & $\mathrm{n}$ & $\mathrm{y}$ \\
\hline Virginia & 600 & $\mathrm{n}$ & $\mathrm{n}$ & $\mathrm{y}$ \\
\hline Washington & 1,450 & $\mathrm{n}$ & $\mathrm{y}$ & $\mathrm{y}$ \\
\hline West Virginia & 1,000 & $\mathrm{n}$ & $\mathrm{y}$ & $\mathrm{n}$ \\
\hline Wisconsin & 1,500 & $\mathrm{n}$ & $\mathrm{n}$ & $\mathrm{y}$ \\
\hline Wyoming & 750 & $\mathrm{n}$ & $\mathbf{n}$ & $\mathrm{y}$ \\
\hline
\end{tabular}

Source: Author's computations using Characteristics of State Plans for AFDC (selected years) and Research Tables Based on Characteristics of State Plans for AFDC (selected years). 


\section{Appendix B: Sample Characteristics}

Full Sample of Female-Headed Households, 1978

\begin{tabular}{|l|c|c|c|}
\hline Variable & Mean & Standard Deviation & Sample Size \\
\hline Total net wealth, 1978 & $4,849.04$ & $17,053.33$ & 391 \\
\hline Total net wealth, 1973 & $3,235.00$ & $12,009.00$ & 391 \\
\hline Gross wealth, 1978 & $7,911.62$ & $22,283.13$ & 391 \\
\hline Gross wealth, 1973 & $5,926.50$ & $18,516.00$ & 391 \\
\hline Liquid wealth, 1978 & 889.77 & $4,916.37$ & 391 \\
\hline Liquid wealth, 1973 & 622.27 & $4,059.40$ & 391 \\
\hline Income, 1978 & $7,287.20$ & $5,701.10$ & 391 \\
\hline Two-person limit, 1978 & $2,460.10$ & $3,009.01$ & 391 \\
\hline Family-size-varying limit, 1978 & $2,839.00$ & 3.477 .50 & 391 \\
\hline Housing test & 0.27 & 0.44 & 391 \\
\hline Gross valuation & 0.81 & 0.39 & 391 \\
\hline Vehicle test & 0.49 & 0.50 & 391 \\
\hline Change in educational attainment & 0.07 & 0.26 & 386 \\
\hline Positive change in dependents, 1973-78 & 0.39 & 0.49 & 386 \\
\hline Negative change in dependents, 1973-78 & 0.09 & 0.28 & 386 \\
\hline Never married & 0.30 & 0.46 & 386 \\
\hline High-school graduate & 0.61 & 0.49 & 386 \\
\hline Number of dependents, 1978 & 2.10 & 1.38 & 386 \\
\hline
\end{tabular}

Sample of Nonrecipient Female-Headed Households, 1978

\begin{tabular}{|l|r|c|c|}
\hline Variable & \multicolumn{1}{l|}{ Mean } & Standard Deviation & Sample Size \\
\hline Total net wealth, 1978 & $6,942.16$ & $20,685.98$ & 256 \\
\hline Total net wealth, 1973 & $4,557.40$ & $14,577.00$ & 256 \\
\hline Income, 1978 & $7,882.80$ & $5,553.70$ & 256 \\
\hline Two-person limit, 1978 & $2,399.80$ & $2,875.90$ & 256 \\
\hline Family-size-varying limit, 1978 & $2,754.20$ & $3,338.60$ & 256 \\
\hline Housing test & 0.24 & 0.43 & 256 \\
\hline Gross valuation & 0.81 & 0.39 & 256 \\
\hline Vehicle test & 0.44 & 0.50 & 256 \\
\hline Change in educational attainment & 0.06 & 0.24 & 254 \\
\hline Positive change in dependents, 1973-78 & 0.35 & 0.47 & 254 \\
\hline Negative change in dependents, 1973-78 & 0.09 & 0.29 & 254 \\
\hline Never married & 0.26 & 0.44 & 254 \\
\hline High-school graduate & 0.68 & 0.47 & 254 \\
\hline Number of dependents, 1978 & 1.83 & 1.22 & 254 \\
\hline
\end{tabular}

Source: Author's computations from the National Longitudinal Survey of Women. 


\section{References}

Blank, R., "The Impact of State Economic Differentials on Household Welfare and Labor Force Behavior." Journal of Public Economics 28, 25-58, 1985.

Blinder, A., and Rosen, H., “Notches.” American Economic Review 75(4), 736-747, 1985.

Davidson, R., and Mackinnon, J., "Several Tests for Model Specification in the Presence of Multiple Alternatives," Econometrica 49, 781-793, 1981.

Feldstein, M., "College Scholarship Rules and Private Saving," American Economic Review 84(3), 552$566,1995$.

Hays, C., "Welfare's Limit on Savings Foils One Bid to Break Cycle." New York Times, May 15, 1992.

Hubbard, R., Skinner, J., and Zeldes, S., "Expanding the Life-Cycle Model: Precautionary Saving and Public Policy." American Economic Review Papers and Proceedings 84 (May), 174-179, 1994(a).

Hubbard, R., Skinner, J., and Zeldes, S., "Precautionary Saving and Social Insurance." NBER Working Paper No. 4884, 1994(b).

Hubbard, R., Skinner, J., and Zeldes, S., "Precautionary Saving and Social Insurance." Journal of Political Economy 103(21), 360-399, 1995.

Lurie, I., "Income, Asset, and Work Tests in Transfer Programs for Able-Bodied Nonaged Individuals," pp. 52-90 in The Treatment of Assets and Income from Assets in Income-Conditioned Government Benefit Programs: Technical Papers Prepared for the Federal Council on Aging. Institute for Research on Poverty, University of Wisconsin, Madison, September 1, 1977.

Moffitt, R., Incentive Effects of the U.S. Welfare System: A Review." Journal of Economic Literature $30(1), 1-61,1992$.

Sherraden, Michael, Assets and the Poor: A New American Welfare Policy. Armonk, NY: Sharpe, 1991.

Skinner, J. “Is Housing Wealth a Sideshow?” NBER Working Paper No. 4552, November 1993.

U.S. Department of Health and Human Services, Characteristics of State Plans for Aid to Families with Dependent Children, selected years.

U.S. Department of Health and Human Services, Research Tables Based on Characteristics of State Plans for Aid to Families with Dependent Children, selected years.

White, H., "A Heteroskedasticity Consistent Covariance Matrix and a Direct Test for Heteroskedasticity." Econometrica, 817-838, 1978. 


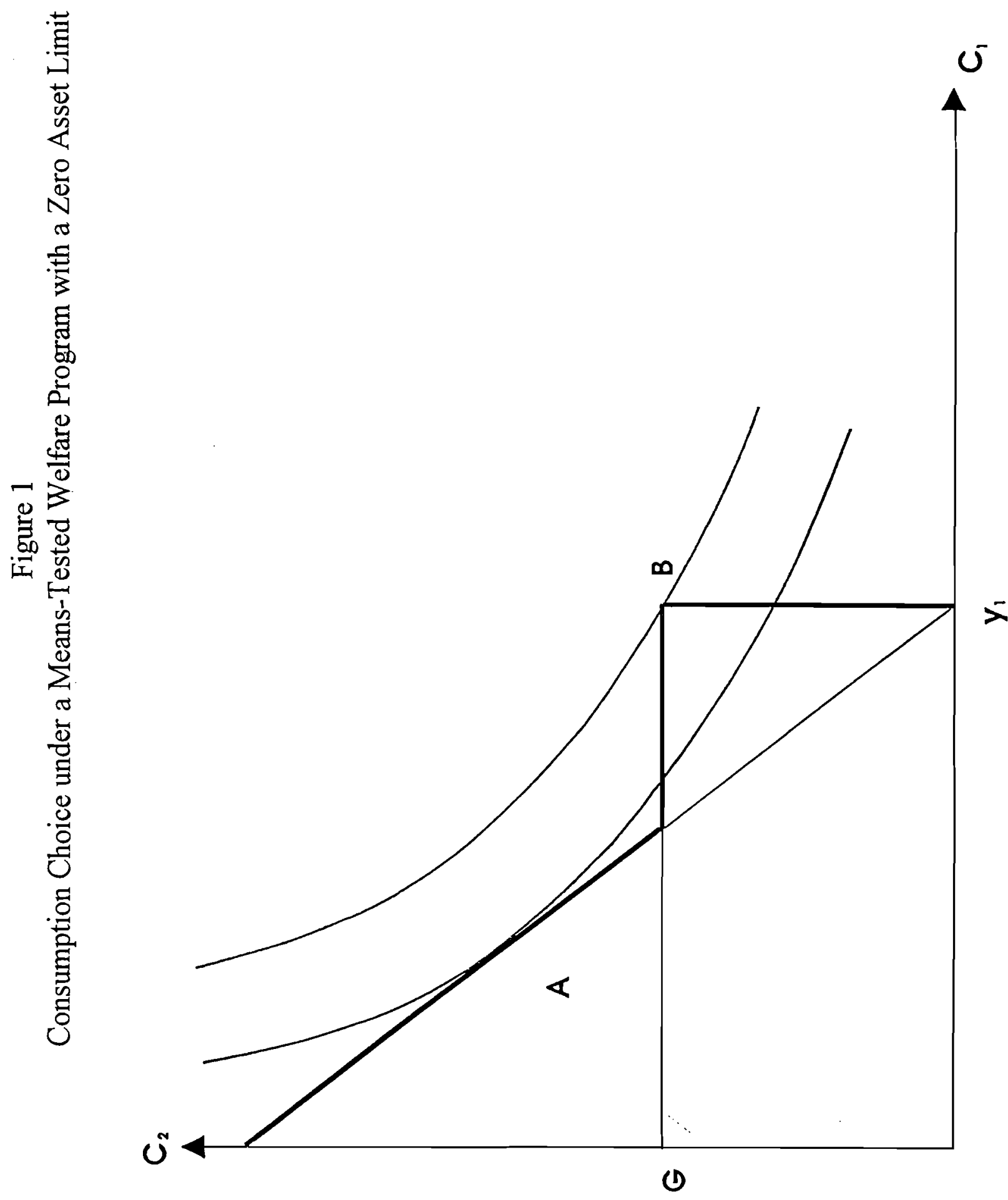




$$
1 / 1
$$



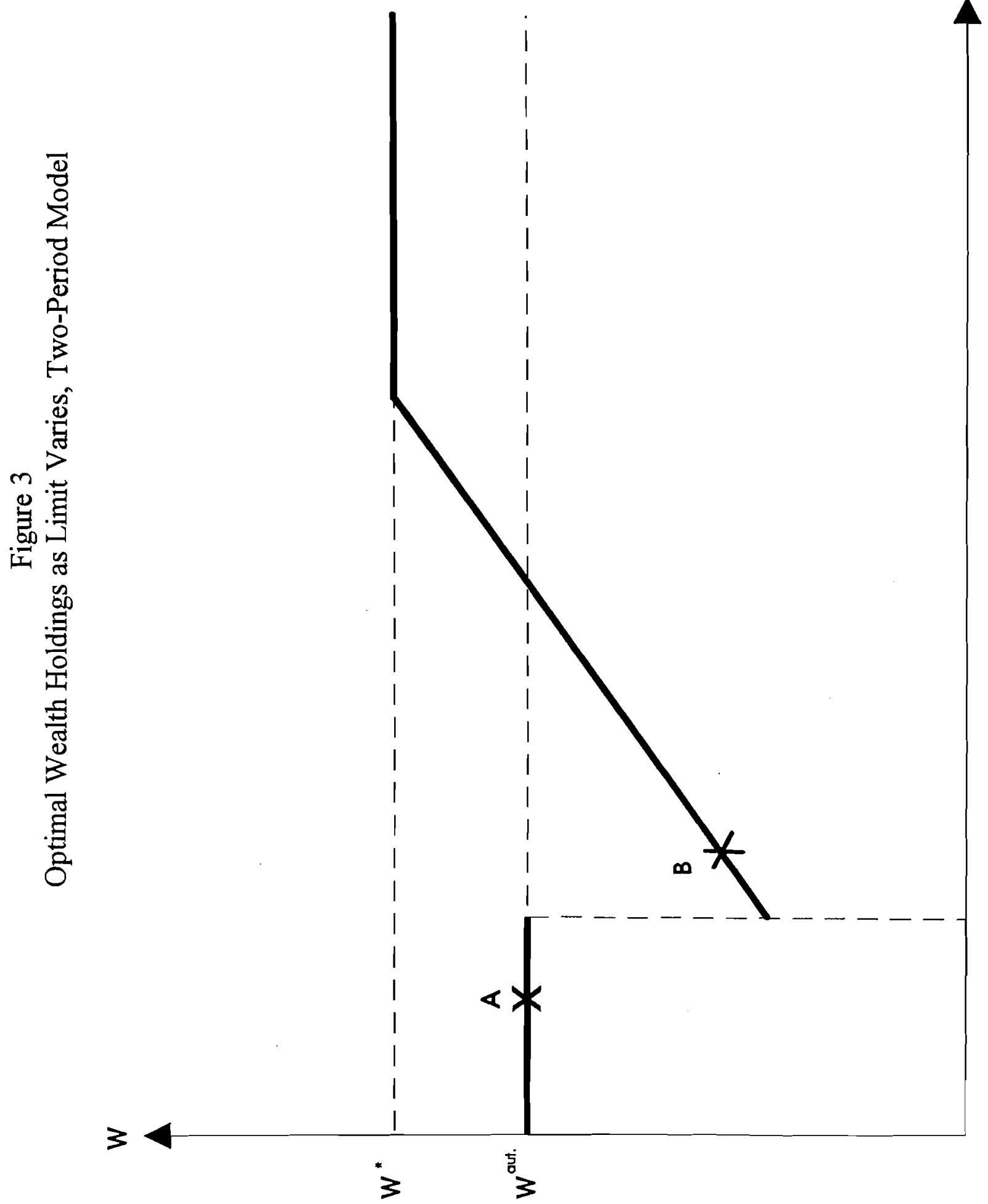
Table 1: Basic Level and Log-Linear Models, by Type of Wealth ${ }^{\mathrm{a}}$

\begin{tabular}{|c|c|c|c|c|c|c|}
\hline & \multicolumn{3}{|c|}{ Levels } & \multicolumn{3}{|c|}{ Logs } \\
\hline Variable & $\begin{array}{c}\text { Net } \\
\text { wealth }\end{array}$ & $\begin{array}{l}\text { Gross } \\
\text { wealth }\end{array}$ & $\begin{array}{l}\text { Liquid } \\
\text { wealth }\end{array}$ & $\begin{array}{c}\text { Net } \\
\text { wealth }^{\mathrm{d}}\end{array}$ & $\begin{array}{l}\text { Gross } \\
\text { wealth }\end{array}$ & $\begin{array}{l}\text { Liquid } \\
\text { wealth }\end{array}$ \\
\hline Constant & $\begin{array}{c}-1,419.20 \\
(0.85)\end{array}$ & $\begin{array}{c}-1,644.50 \\
(0.67)\end{array}$ & $\begin{array}{c}-844.90 \\
(1.32)\end{array}$ & $\begin{array}{l}-3.82^{*} \\
(1.99)\end{array}$ & $\begin{array}{l}-3.84^{* * *} \\
(1.89)\end{array}$ & $\begin{array}{l}-1.60 \\
(0.94)\end{array}$ \\
\hline 1978 Income $^{b}$ & $\begin{array}{c}0.52^{*} \\
(1.98)\end{array}$ & $\begin{array}{c}0.76^{*} \\
(2.51)\end{array}$ & $\begin{array}{c}0.19^{*} \\
(2.19)\end{array}$ & $\begin{array}{l}-0.82^{*} \\
(2.24)\end{array}$ & $\begin{array}{l}-1.01^{*} \\
(2.63)\end{array}$ & $\begin{array}{l}-1.16^{*} \\
(4.14)\end{array}$ \\
\hline$\left(1978 \text { Income }^{b}\right)^{2}$ & $\begin{array}{c}-8.50 \mathrm{E}-06^{* * *} \\
(1.53)\end{array}$ & $\begin{array}{c}-1.20 \mathrm{E}-05^{* *} \\
(1.88)\end{array}$ & $\begin{array}{c}-2.40 \mathrm{E}-06 \\
(1.16)\end{array}$ & $\begin{array}{c}0.10^{*} \\
(2.74)\end{array}$ & $\begin{array}{l}0.12^{*} \\
(3.32)\end{array}$ & $\begin{array}{c}0.14^{*} \\
(4.81)\end{array}$ \\
\hline Limit, two-person family, $1978^{\mathrm{b}}$ & $\begin{array}{c}0.48^{*} \\
(2.21)\end{array}$ & $\begin{array}{c}0.34 \\
(1.29)\end{array}$ & $\begin{array}{l}0.17^{* * *} \\
(1.51)\end{array}$ & $\begin{array}{c}0.70^{*} \\
(3.31)\end{array}$ & $\begin{array}{c}0.68^{*} \\
(3.12)\end{array}$ & $\begin{array}{l}0.36^{* *} \\
(0.06)\end{array}$ \\
\hline House tested, $1978^{\circ}$ & $\begin{array}{c}-3,419.20^{*} \\
(2.64)\end{array}$ & $\begin{array}{c}-3,305.40^{* *} \\
(1.81)\end{array}$ & $\begin{array}{c}-523.09 \\
(1.02)\end{array}$ & $\begin{array}{c}0.04 \\
(0.08)\end{array}$ & $\begin{array}{l}-0.11 \\
(0.22)\end{array}$ & $\begin{array}{c}-0.13 \\
(0.35)\end{array}$ \\
\hline Market valuation for test, $1978^{\circ}$ & $\begin{array}{c}-745.50 \\
(0.49)\end{array}$ & $\begin{array}{c}-1,351.80 \\
(0.56)\end{array}$ & $\begin{array}{c}-132.20 \\
(0.28)\end{array}$ & $\begin{array}{l}0.90^{* *} \\
(1.70)\end{array}$ & $\begin{array}{l}0.95^{* *} \\
(1.70)\end{array}$ & $\begin{array}{c}-0.02 \\
(0.04)\end{array}$ \\
\hline Car tested, $1978^{\circ}$ & $\begin{array}{l}109.60 \\
(0.12)\end{array}$ & $\begin{array}{c}1,505.40 \\
(1.21)\end{array}$ & $\begin{array}{c}-236.40 \\
(0.93)\end{array}$ & $\begin{array}{l}-0.28 \\
(0.80)\end{array}$ & $\begin{array}{l}-0.05 \\
(0.15)\end{array}$ & $\begin{array}{c}0.14 \\
(0.49)\end{array}$ \\
\hline Wealth, 1973 & $\begin{array}{r}1.08^{*} \\
(6.78) \\
\end{array}$ & $\begin{array}{c}0.93^{*} \\
(9.99)\end{array}$ & $\begin{array}{c}0.80^{\circ} \\
(2.22) \\
\end{array}$ & $\begin{array}{c}0.52^{*} \\
(10.47) \\
\end{array}$ & $\begin{array}{c}0.53^{*} \\
(10.66)\end{array}$ & $\begin{array}{c}0.43^{*} \\
(7.87)\end{array}$ \\
\hline Number of observations & 391 & 391 & 391 & 391 & 391 & 391 \\
\hline Adjusted $\mathrm{R}^{2}$ & $61.0 \%$ & $63.4 \%$ & $46.4 \%$ & $35.3 \%$ & $39.0 \%$ & $33.1 \%$ \\
\hline
\end{tabular}

Notes: $\quad$ 'Standard errors of model estimates adjusted by White's heteroskedasticity correction.

${ }^{b}$ Corresponding log value implied in case of log-linear model.

' Binary variable corresponds to one if statement is true.

${ }^{d}$ Negative values of net wealth are set to zero.

* Significant at $95 \%$ level of confidence.

"Significant at $90 \%$ level of confidence.

-... Significant at $85 \%$ level of confidence.

Source: Author's computations based on data from the National Longitudinal Survey of Women. 
clevelandfed.org/research/workpaper/index.cfm

Table 2: Extended Level and Log-Linear Models, with and without Lagged Endogenous Variable

\begin{tabular}{|c|c|c|c|c|}
\hline & \multicolumn{2}{|c|}{ Levels } & \multicolumn{2}{|c|}{$\operatorname{Logs}^{d}$} \\
\hline Variable & $\begin{array}{c}\text { Including } \\
\text { lagged wealth }\end{array}$ & $\begin{array}{c}\text { Excluding } \\
\text { lagged wealth }\end{array}$ & $\begin{array}{c}\text { Including } \\
\text { lagged wealth }\end{array}$ & $\begin{array}{c}\text { Excluding } \\
\text { lagged wealth }\end{array}$ \\
\hline Constant & $\begin{array}{c}-2,626.50 \\
(1.18)\end{array}$ & $\begin{array}{c}-2,084.10 \\
(0.68)\end{array}$ & $\begin{array}{l}-3.24^{* *} \\
(1.89)\end{array}$ & $\begin{array}{l}-1.74 \\
(0.79)\end{array}$ \\
\hline 1978 Income $^{b}$ & $\begin{array}{l}0.48^{* *} \\
(1.67)\end{array}$ & $\begin{array}{l}0.66^{* * *} \\
(1.47)\end{array}$ & $\begin{array}{l}-0.72^{*} \\
(1.99)\end{array}$ & $\begin{array}{l}-1.22^{*} \\
(2.76)\end{array}$ \\
\hline$\left.(1978 \text { Income })^{b}\right)^{2}$ & $\begin{array}{c}-7.50 \mathrm{E}-06 \\
(1.26)\end{array}$ & $\begin{array}{c}-3.20 \mathrm{E}-06 \\
(0.28)\end{array}$ & $\begin{array}{l}0.08^{*} \\
(2.38)\end{array}$ & $\begin{array}{l}0.15^{*} \\
(3.59)\end{array}$ \\
\hline Limit, two-person family, $1978^{\mathrm{b}}$ & $\begin{array}{l}0.47^{*} \\
(2.11)\end{array}$ & $\begin{array}{c}0.38 \\
(1.11)\end{array}$ & $\begin{array}{l}0.60^{*} \\
(3.16)\end{array}$ & $\begin{array}{l}0.61^{*} \\
(2.93)\end{array}$ \\
\hline House tested, $1978^{c}$ & $\begin{array}{c}-3,905.7^{\circ} \\
(2.94)\end{array}$ & $\begin{array}{l}-436.00 \\
(0.22)\end{array}$ & $\begin{array}{c}0.08 \\
(0.17)\end{array}$ & $\begin{array}{c}0.55 \\
(1.07)\end{array}$ \\
\hline Market valuation for test, $1978^{\circ}$ & $\begin{array}{c}-1,198.60 \\
(0.81)\end{array}$ & $\begin{array}{l}1,459.60 \\
(0.69)\end{array}$ & $\begin{array}{l}1.01^{* *} \\
(1.95)\end{array}$ & $\begin{array}{c}0.81 \\
(1.42)\end{array}$ \\
\hline Car tested, $1978^{\circ}$ & $\begin{array}{l}156.50 \\
(0.16)\end{array}$ & $\begin{array}{c}-1,070.70 \\
(0.76)\end{array}$ & $\begin{array}{l}-0.09 \\
(0.24)\end{array}$ & $\begin{array}{l}-0.25 \\
(0.62)\end{array}$ \\
\hline Wealth, 1973 & $\begin{array}{l}1.08^{*} \\
(6.76)\end{array}$ & & $\begin{array}{l}0.45^{*} \\
(8.19)\end{array}$ & \\
\hline $\begin{array}{l}\text { Increased number of } \\
\text { dependents, } 1973-78^{\circ}\end{array}$ & $\begin{array}{l}-830.20 \\
(0.76)\end{array}$ & $\begin{array}{c}-1,103.70 \\
(0.71)\end{array}$ & $\begin{array}{c}-0.56 * * \\
(1.58)\end{array}$ & $\begin{array}{c}-0.54^{* * *} \\
(1.44)\end{array}$ \\
\hline $\begin{array}{l}\text { Decreased number of } \\
\text { dependents, } 1973-78^{c}\end{array}$ & $\begin{array}{l}802.00 \\
(0.45)\end{array}$ & $\begin{array}{l}407.60 \\
(0.17)\end{array}$ & $\begin{array}{l}-0.19 \\
(0.30)\end{array}$ & $\begin{array}{l}-0.09 \\
(0.13)\end{array}$ \\
\hline Change in education, $1973-78^{c}$ & $\begin{array}{l}2,273.40 \\
(0.82)\end{array}$ & $\begin{array}{l}6,789.50 \\
(0.95)\end{array}$ & $\begin{array}{l}-0.31 \\
(0.46)\end{array}$ & $\begin{array}{l}-0.49 \\
(0.69)\end{array}$ \\
\hline Never married, $1978^{\circ}$ & $\begin{array}{l}638.20 \\
(0.69)\end{array}$ & $\begin{array}{c}-4,248.40^{*} \\
(2.85)\end{array}$ & $\begin{array}{l}-0.62^{* * *} \\
(1.58)\end{array}$ & $\begin{array}{l}-1.85^{*} \\
(4.70)\end{array}$ \\
\hline High-school graduate, $1978^{\circ}$ & $\begin{array}{c}1,070.4 \\
(0.97)\end{array}$ & $\begin{array}{c}3,742.4^{\circ} \\
(2.26)\end{array}$ & $\begin{array}{c}1.42^{\circ} \\
(3.80)\end{array}$ & $\begin{array}{l}2.08^{*} \\
(4.88)\end{array}$ \\
\hline Number of dependents, 1978 & $\begin{array}{l}531.50 \\
(1.39) \\
\end{array}$ & $\begin{array}{c}-101.78 \\
(0.17) \\
\end{array}$ & $\begin{array}{c}-0.18 \\
(0.13) \\
\end{array}$ & $\begin{array}{c}-0.11 \\
(0.72) \\
\end{array}$ \\
\hline $\begin{array}{l}\text { Number of observations } \\
\text { Adjusted } \mathrm{R}^{2}\end{array}$ & $\begin{array}{r}386 \\
60.7 \% \\
\end{array}$ & $\begin{array}{r}386 \\
6.4 \% \\
\end{array}$ & $\begin{array}{r}386 \\
36.8 \% \\
\end{array}$ & $\begin{array}{r}386 \\
24.0 \% \\
\end{array}$ \\
\hline
\end{tabular}

Notes: ' $\quad$ Standard errors of model estimates adjusted by White's heteroskedasticity correction.

${ }^{b}$ Corresponding log value implied in case of log-linear model.

${ }^{c}$ Binary variable corresponds to one if statement is true.

"Negative values of net wealth are set to zero.

Significant at $95 \%$ level of confidence.

"Significant at $90 \%$ level of confidence.

-.. Significant at $85 \%$ level of confidence.

Source: Author's computations based on data from the National Longitudinal Survey of Women. 
clevelandfed.org/research/workpaper/index.cfm

Table 3: Basic Level and Log Models, with and without State Effects ${ }^{\mathrm{a}}$

\begin{tabular}{|c|c|c|c|c|}
\hline & \multicolumn{2}{|c|}{ Levels } & \multicolumn{2}{|c|}{$\log s^{c}$} \\
\hline Variable & $\begin{array}{c}\text { Excluding } \\
\text { state dummies }\end{array}$ & $\begin{array}{c}\text { Including } \\
\text { state dummies }\end{array}$ & $\begin{array}{c}\text { Excluding } \\
\text { state dummies }\end{array}$ & $\begin{array}{c}\text { Including } \\
\text { state dummies }\end{array}$ \\
\hline Constant & $\begin{array}{c}-2,181.00^{* * * *} \\
(1.58)\end{array}$ & NA & $\begin{array}{l}-1.17 \\
(0.81)\end{array}$ & NA \\
\hline 1978 Income & $\begin{array}{l}0.48^{* *} \\
(1.87)\end{array}$ & $\begin{array}{l}0.38^{* * *} \\
(1.63)\end{array}$ & $\begin{array}{l}-0.87^{*} \\
(2.39)\end{array}$ & $\begin{array}{l}-0.78^{* *} \\
(1.95)\end{array}$ \\
\hline$(1978 \text { Income })^{b}$ & $\begin{array}{c}-7.90 \mathrm{E}-06 \\
(1.43)\end{array}$ & $\begin{array}{c}-5.80 \mathrm{E}-06 \\
(1.10)\end{array}$ & $\begin{array}{l}0.10^{*} \\
(2.88)\end{array}$ & $\begin{array}{c}-9.80 \mathrm{E}-02^{*} \\
(2.76)\end{array}$ \\
\hline Family size, varying limit, $1978^{\mathrm{b}}$ & $\begin{array}{l}0.25^{* *} \\
(1.73)\end{array}$ & $\begin{array}{c}0.53^{*} \\
(2.04)\end{array}$ & $\begin{array}{c}0.42^{*} \\
(2.56)\end{array}$ & $\begin{array}{c}0.48 \\
(0.53)\end{array}$ \\
\hline Wealth, 1973 & $\begin{array}{c}1.08^{*} \\
(6.49)\end{array}$ & $\begin{array}{r}1.14^{*} \\
(8.97) \\
\end{array}$ & $\begin{array}{c}0.52^{*} \\
(10.36)\end{array}$ & $\begin{array}{c}0.49^{*} \\
(9.53) \\
\end{array}$ \\
\hline Number of observations & 391 & 391 & 391 & 391 \\
\hline Adjusted $\mathrm{R}^{2}$ & $60.8 \%$ & $63.4 \%$ & $35.1 \%$ & $34.4 \%$ \\
\hline
\end{tabular}

Notes: ${ }^{a}$ Standard errors of model estimates adjusted by White's heteroskedasticity correction.

${ }^{\mathrm{b}}$ Corresponding log value implied in case of log-linear model.

${ }^{c}$ Negative values of net wealth are set to zero.

- Significant at $95 \%$ level of confidence.

"Significant at $90 \%$ level of confidence.

"** Significant at $85 \%$ level of confidence.

Source: Author's computations based on data from the National Longitudinal Survey of Women. 
clevelandfed.org/research/workpaper/index.cfm

Table 4: Instrumental Variable Estimates of Wealth ${ }^{\mathrm{a}}$

\begin{tabular}{|c|c|c|c|c|}
\hline & \multicolumn{2}{|c|}{ Levels } & \multicolumn{2}{|c|}{$\log s^{c}$} \\
\hline Variable & $\begin{array}{l}\text { Excluding } \\
\text { instrument for limit }\end{array}$ & $\begin{array}{c}\text { Including } \\
\text { instrument for limit }\end{array}$ & $\begin{array}{c}\text { Excluding } \\
\text { instrument for limit }\end{array}$ & $\begin{array}{c}\text { Including } \\
\text { instrument for limit }\end{array}$ \\
\hline Constant & $\begin{array}{c}-2,214.50^{* * *} \\
(1.60)\end{array}$ & $\begin{array}{c}-2,154.30^{* * *} \\
(1.57)\end{array}$ & $\begin{array}{l}-1.38 \\
(0.82)\end{array}$ & $\begin{array}{l}-2.04 \\
(1.27)\end{array}$ \\
\hline 1978 Income & $\begin{array}{l}0.48^{* *} \\
(1.87)\end{array}$ & $\begin{array}{l}0.49^{* *} \\
(1.88)\end{array}$ & $\begin{array}{l}-0.87^{*} \\
(2.34)\end{array}$ & $\begin{array}{l}-0.87^{*} \\
(2.38)\end{array}$ \\
\hline$\left(1978 \text { Income }^{b}\right)^{2}$ & $\begin{array}{c}-7.90 \mathrm{E}-06 \\
(1.43)\end{array}$ & $\begin{array}{c}-8.00 \mathrm{E}-06^{* * *} \\
(1.44)\end{array}$ & $\begin{array}{l}0.10^{*} \\
(3.15)\end{array}$ & $\begin{array}{l}0.10^{*} \\
(2.85)\end{array}$ \\
\hline Limit, two-person family, $1978^{b}$ & $\begin{array}{l}0.311^{*} \\
(1.61)\end{array}$ & $\begin{array}{c}0.27 \\
(1.36)\end{array}$ & $\begin{array}{l}0.45^{*} \\
(2.57)\end{array}$ & $\begin{array}{l}0.55^{*} \\
(2.73)\end{array}$ \\
\hline Wealth, 1973 & $\begin{array}{r}1.08^{\circ} \\
(6.46) \\
\end{array}$ & $\begin{array}{r}1.08^{*} \\
(6.47) \\
\end{array}$ & $\begin{array}{c}0.51^{*} \\
(11.17) \\
\end{array}$ & $\begin{array}{c}0.51^{*} \\
(10.13) \\
\end{array}$ \\
\hline Number of observations & 391 & 391 & 391 & 391 \\
\hline Adjusted $\mathrm{R}^{2}$ & $60.8 \%$ & $60.8 \%$ & $35.1 \%$ & $35.1 \%$ \\
\hline
\end{tabular}

Notes: $\quad$ a Standard errors of model estimates adjusted by White's heteroskedasticity correction.

${ }^{b}$ Corresponding log value implied in case of log-linear model.

${ }^{c}$ Negative values of net wealth are set to zero.

Significant at $95 \%$ level of confidence.

". Significant at $90 \%$ level of confidence.

"** Significant at $85 \%$ level of confidence.

Source: Author's computations based on data from the National Longitudinal Survey of Women. 
Table 5. clevelandfed,org/research/workpaper/index.cfm

\begin{tabular}{|c|c|c|c|c|c|c|c|c|}
\hline \multirow[b]{2}{*}{ Variable } & \multicolumn{2}{|c|}{ Parsimonious Model } & \multicolumn{2}{|c|}{ Extended Model } & \multicolumn{2}{|c|}{ State Effects } & \multicolumn{2}{|c|}{$\begin{array}{c}\text { Instrumental Variable } \\
\text { Estimate }\end{array}$} \\
\hline & Levels & $\operatorname{Logs}^{d}$ & Levels & $\operatorname{Logs}^{d}$ & Levels & $\log ^{d}$ & Levels & $\operatorname{Logs}^{d}$ \\
\hline Constant & $\begin{array}{c}-359.80 \\
(0.14)\end{array}$ & $\begin{array}{l}-3.71^{* *} \\
(1.77)\end{array}$ & $\begin{array}{l}-3,227.70 \\
(0.88)\end{array}$ & $\begin{array}{l}-3.10^{* * *} \\
(1.52)\end{array}$ & no & no & $\begin{array}{c}-1,708.70 \\
(0.82)\end{array}$ & $\begin{array}{l}-2.92^{* *} \\
(1.55)\end{array}$ \\
\hline 1978 Income & $\begin{array}{c}0.40 \\
(0.94)\end{array}$ & $\begin{array}{l}-0.39 \\
(0.99)\end{array}$ & $\begin{array}{c}0.28 \\
(0.60)\end{array}$ & $\begin{array}{l}-0.31 \\
(0.81)\end{array}$ & $\begin{array}{c}0.05 \\
(0.12)\end{array}$ & $\begin{array}{l}-0.43 \\
(1.09)\end{array}$ & $\begin{array}{c}0.37 \\
(0.90)\end{array}$ & $\begin{array}{l}-0.50 \\
(1.22)\end{array}$ \\
\hline$\left(1978 \text { Income }^{\mathrm{b}}\right)^{2}$ & $\begin{array}{c}2.47 \mathrm{E}-06 \\
(0.18)\end{array}$ & $\begin{array}{l}5.80 \mathrm{E}-02^{* * *} \\
(1.45)\end{array}$ & $\begin{array}{l}1.09 \mathrm{E}-06 \\
(0.08)\end{array}$ & $\begin{array}{l}4.20 \mathrm{E}-02 \\
(1.11)\end{array}$ & $\begin{array}{l}1.08 \mathrm{E}-05 \\
(0.82)\end{array}$ & $\begin{array}{l}0.06 * * \\
(1.50)\end{array}$ & $\begin{array}{c}-1.90 \mathrm{E}-06 \\
(0.14)\end{array}$ & $\begin{array}{l}6.7 \mathrm{E}-02^{* *} \\
(1.64)\end{array}$ \\
\hline Limit, two-person family, $1978^{b}$ & $\begin{array}{l}0.71^{*} \\
(2.13)\end{array}$ & $\begin{array}{l}0.61^{*} \\
(2.64)\end{array}$ & $\begin{array}{l}0.70^{*} \\
(2.07)\end{array}$ & $\begin{array}{l}0.49^{*} \\
(2.28)\end{array}$ & no & no & $\begin{array}{c}0.43 \\
(1.30)\end{array}$ & $\begin{array}{c}0.67^{*} \\
(2.63)\end{array}$ \\
\hline Family size, varying limit, $1978^{\mathrm{b}}$ & no & no & no & no & $\begin{array}{l}0.49^{* *} \\
(1.94)\end{array}$ & $\begin{array}{c}0.01 \\
(0.01)\end{array}$ & no & no \\
\hline House tested, $1978^{\circ}$ & $\begin{array}{c}-4,512.00^{*} \\
(2.18)\end{array}$ & $\begin{array}{l}0.90^{* * *} \\
(1.50)\end{array}$ & $\begin{array}{c}-4,959.60^{*} \\
(2.45)\end{array}$ & $\begin{array}{l}0.82^{* * *} \\
(1.45)\end{array}$ & no & no & no & no \\
\hline Market valuation for test, $1978^{\circ}$ & $\begin{array}{c}-1,358.10 \\
(0.63)\end{array}$ & $\begin{array}{l}1.13^{* *} \\
(1.75)\end{array}$ & $\begin{array}{c}-1,649.90 \\
(0.80)\end{array}$ & $\begin{array}{l}1.17^{* *} \\
(1.83)\end{array}$ & no & no & no & no \\
\hline Car tested, $1978^{\mathrm{c}}$ & $\begin{array}{l}-41.13 \\
(0.03)\end{array}$ & $\begin{array}{l}-0.36 \\
(0.83)\end{array}$ & $\begin{array}{l}363.60 \\
(0.25)\end{array}$ & $\begin{array}{l}-0.16 \\
(0.35)\end{array}$ & no & no & no & no \\
\hline Wealth, 1973 & $\begin{array}{c}1.08^{*} \\
(6.78)\end{array}$ & $\begin{array}{c}0.53^{*} \\
(8.81)\end{array}$ & $\begin{array}{c}1.07^{*} \\
(6.73)\end{array}$ & $\begin{array}{l}0.46^{*} \\
(7.06)\end{array}$ & $\begin{array}{l}1.10^{*} \\
(9.06)\end{array}$ & $\begin{array}{l}0.51^{*} \\
(7.95)\end{array}$ & $\begin{array}{c}1.07^{*} \\
(6.36)\end{array}$ & $\begin{array}{c}0.52^{*} \\
(8.21)\end{array}$ \\
\hline $\begin{array}{l}\text { Increased number of dependents, } \\
1973-78^{c}\end{array}$ & no & no & $\begin{array}{c}-1,545.60 \\
(0.92)\end{array}$ & $\begin{array}{l}-1.00^{*} \\
(2.31)\end{array}$ & no & no & no & no \\
\hline $\begin{array}{l}\text { Decreased number of } \\
\text { dependents, } 1973-78^{\circ}\end{array}$ & no & no & $\begin{array}{c}2,096.90 \\
(0.85)\end{array}$ & $\begin{array}{c}0.32 \\
(0.45)\end{array}$ & no & no & no & no \\
\hline Change in education, $1973-78^{\circ}$ & no & no & $\begin{array}{c}4,109.50 \\
(0.96)\end{array}$ & $\begin{array}{c}0.23 \\
(0.32)\end{array}$ & no & no & no & no \\
\hline Never married, $1978^{\mathrm{c}}$ & no & no & $\begin{array}{c}388.50 \\
(0.28)\end{array}$ & $\begin{array}{l}-0.52 \\
(1.07)\end{array}$ & no & no & no & no \\
\hline High-school graduate, $1978^{\circ}$ & no & no & $\begin{array}{c}1,645.80 \\
(0.92)\end{array}$ & $\begin{array}{c}1.53^{*} \\
(3.21)\end{array}$ & no & no & no & no \\
\hline $\begin{array}{l}\text { Number of dependents, } 1978 \\
\text { State effects }\end{array}$ & $\begin{array}{l}\text { no } \\
\text { no }\end{array}$ & $\begin{array}{l}\text { no } \\
\text { no }\end{array}$ & $\begin{array}{c}1,375.70^{*} \\
(2.00) \\
\text { no }\end{array}$ & $\begin{array}{c}0.22 \\
(1.10) \\
\text { no } \\
\end{array}$ & $\begin{array}{l}\text { no } \\
\text { yes }\end{array}$ & $\begin{array}{l}\text { no } \\
\text { yes }\end{array}$ & $\begin{array}{l}\text { no } \\
\text { no }\end{array}$ & $\begin{array}{l}\text { no } \\
\text { no }\end{array}$ \\
\hline $\begin{array}{l}\text { Number of observations } \\
\text { Adjusted } \mathrm{R}^{2}\end{array}$ & $\begin{array}{c}256 \\
60.6 \%\end{array}$ & $\begin{array}{c}256 \\
38.1 \%\end{array}$ & $\begin{array}{c}254 \\
60.4 \%\end{array}$ & $\begin{array}{c}254 \\
39.4 \%\end{array}$ & $\begin{array}{r}256 \\
65.6 \%\end{array}$ & $\begin{array}{c}256 \\
36.0 \%\end{array}$ & $37.9 \%$ & $37.6 \%$ \\
\hline
\end{tabular}

Notes: "Standard errors of model estimates adjusted by White's heteroskedasticity correction.

${ }^{b}$ Corresponding log value implied in case of log-linear model.

${ }^{c}$ Binary variable corresponds to one if statement is true.

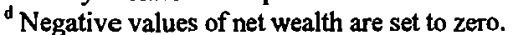

- Significant at $95 \%$ level of confidence.

- Significant at $90 \%$ level of confidence.

"... Significant at $85 \%$ level of confidence.

Source: Author's computations based on data from the National Longitudinal Survey of Women. 